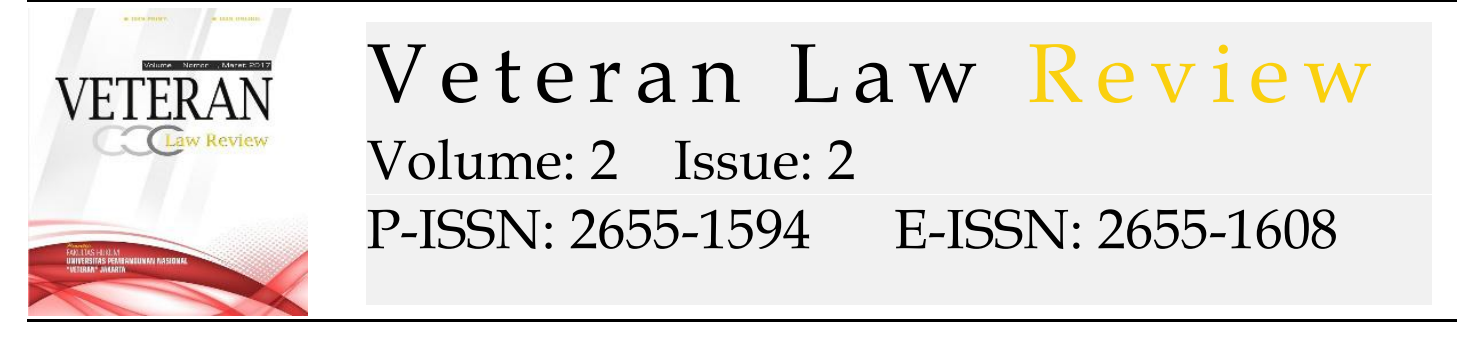

\title{
Business Actors' Responsibility Towards Consumers Due To Defective Product
}

\author{
Ni Ketut Sari Adnyani1, Dewa Gede Sudika Mangku² \\ ${ }^{1}$ Law Department, Faculty of Law and Social Science, Unversitas Pendidikan Ganesha, \\ Singaraja, Bali, Indonesia, E-mail:niktsariadnyani@gmail.com \\ ${ }^{2}$ Law Department, Faculty of Law and Social Science, Unversitas Pendidikan Ganesha, \\ Singaraja, Bali, Indonesia, E-mail: dewamangku.undiksha@gmail.com
}

\begin{tabular}{|c|c|}
\hline ARTICLE INFO & ABSTRACT \\
\hline $\begin{array}{l}\text { Keywords: } \\
\text { defective product; business } \\
\text { actors; protection; } \\
\text { regulations. } \\
\text { How to cite: } \\
\text { Adnyani, N. K.S., \& G. } \\
\text { S.M. Dewa. (2019). } \\
\text { Business Actors' } \\
\text { Responsibility Towards } \\
\text { Consumers Due To } \\
\text { Defective Product. } \\
\text { Veteran Law Review. 2(2). } \\
\text { Hlm. 1-5 }\end{array}$ & $\begin{array}{l}\text { This study aims to examine the form of business actor's } \\
\text { responsibilities to consumers in terms of defective products, following } \\
\text { up on efforts that can be taken if there are business actors who do not } \\
\text { fulfill their responsibilities. The research method in normative and } \\
\text { empirical legal research, and the type of research is a comprehensive } \\
\text { analytical study of primary legal materials, secondary legal materials } \\
\text { and tertiary legal materials. Using empirical legal research approach } \\
\text { methods, the approarch is the statutory approach and the fact } \\
\text { approach. The focus of normative legal research is an inventory of } \\
\text { written positive law mainly concerning the regulation of the } \\
\text { rsponsibilities of business actors in buying and selling in the } \\
\text { perspective of the Consumer Protection Law No.8 of 1999, the Civil } \\
\text { Code (KUHP), and regulations concerning defective products. } \\
\text { Research is a descriptive study using qualitative. Determination of } \\
\text { subjects in this study using Simple Random Sampling technique. } \\
\text { Empirical legal research, targeting aspects of justice, usefulness, and } \\
\text { legal certainty based on the Sociological Jurisprudence flow. Research } \\
\text { results: Business actors are responsible if the product dects that occur } \\
\text { are entirely wrong. The effort taken of the business actor does not } \\
\text { want to be responsible for the occurrence of product defects in the sale } \\
\text { and purchase transaction is by solving the Dispute Resolution and } \\
\text { familial approach. If it doesn't work, then it can be reached through a } \\
\text { court. } \\
\text { Copyright @2019 VELREV. All rights reserved. }\end{array}$ \\
\hline
\end{tabular}

\section{Introduction}

The influence of the flow of globalization and free trade which is supported by the advancement of communication and information technology has expanded the space for the flow of goods transactions(Putra, 2014), both within and outside the country. This process effects the social dynamics of people in the world today has undergone rapid changes. This is marked by spectacular developments in information technology and communication technology. Product marketing is not only done through mass media but also through virtual world. The sale and purchase of goods, which were initially conventional in nature, slowly changed to buying and selling goods electrinically, reaching mrchants throughout the world. 
Economic development and development in many countries, especially in the fields of industry and trade, have resulted in a variety of googs and/or services that can be consumed (Thornton, 2010). The logical consequence is that the goods circulating are detrimental to consumers because the conditions of goods that are suitable for consumption by consumers are not fulfilled (Janus, 2014). On the othe hand, the above conditions can also cause the position of business actors and consumers to become unbalanced, it is important to have a consumer protection arrangement (Miru \& Yodo, 2011). Consumer protection must receive more attention, because foreign in investment has become part of Indonesia's economic development and in the world of international trade consumer protection is needed because it is a way to fend off the begative implications for the protection of Indonesian consumers. Violations of consumer rights need to be overcome by legislation in order to improve the dignity of consumers and increase awareness, concern, ability, knowledge and independence of consumers to protect their rights, and develop the attitude of responsible business actors.

Business actors with capacity as providers of goods and/or service. In the midst of competition in the competitive (Katsoulacos, 2016), professional nature is one of the absolute requirements in terms of demanding accountability from business actors. According to Ernes Barker, so that the rights of consumers are prefect, they must fulfill 3 (three) conditions, namely the right is needed for human development, the right is recognized by the community and the right is stated as such and therefore protected and guaranteed by state institution(Adrian Sutendi, 2008). The existence of a legal basis and the existence of legal events is a legal relationship requirement(Soeroso, 2006). Basic arrangements for business actors' responsibility for detective products. Defective products according to the National Legal Development Agency (BPHN) are "Products that cannot fulfill their manufacturing objectives, either due to intentional or negligence in the expect. production process or due to othe things that occur in circulation, or do not provide security requirements for humans or property their objects in their use, as one would expect (Claudya, 2018).From this limitation it can be seen that the responsible party is the product-making business actor in terms of guaranteeing justice, usefulness, and legal certainty(Ahmad Ali, 2002).

Accountability in the sale and purchase transaction, then the business actor can still be held accountable, especially if the product being transacted is defective and detrimental to consumers (Muslih, 2013). Some things that become obstacles when consumers buy and sell ask for accountability, namely the difference/distance between the business actor and the consumer, the legal differences used if the transaction is different countries, the time of compensation is short, the weakness of the Act, the lack of consumer knowledge about consumer protection (Wijaya, 2000). The effectiveness of law enforcement according to Lawrence Friedman is determined by material factors (content of the Act), culture (culture) and institutions including the process. Material (content) of the Civil Code and the Consumer Protection Law have not explicitly regulated the responsibility of the perpetrator 
business in buying and selling that transcends the regulated national boundaries is only traditional trade.

The responsibility of business actors has not been specifically regulated in the Consumer Protection Act, but in principle business actors can be held accountable for buying and selling through contractual liability related to losses experienced by consumers produces (Kurniawan \& Martin, 2014). Product liability if it turns out that the product offered by the business actor is defective and detrimental to the consumer (Anna Gerbrandy, 2018). In reality the demand for responsibility towards business actors is still hampered due to the implementation of the standard agreement in the contracy and the need for proof to demand the responsibility of the business actor in buying and selling.

\section{Method}

The research method that will be used is normative legal research methods, and the type of research is a comprehensive analytical study of primary legal materials, secondary legal materials and legal materials tertiary (Borg and Gall, 1989). The selection of selection of selective legal materials is guided according to the opinions of legal experts from relevant legal materials.

Normative legal research examines written law from various aspects, namely theory, history, philosophy, comparison, structure and composition, scope and material, consistency, general explanation and article by article, formality and binding power of law, and legal language used and empirical law based on the Sociological Jurisprudence flow examines its applied aspects. Normative legal research examines laws that are conceptualized as norms or rules that apply in society and become a reference for everyone's behavior.The prevailing legal norms are in the form of written positive legal norms, especially concerning the regulation of the responsibilities of business actors in buying and selling in the perspective of Consumer Protection Act No. 8 of 1999 and regulations concerning defective products. The method of empirical legal research approach is used as a reference, so the approach is the statutory approach and the fact approach. This type of research is qualitative research (Bungin, 2008). Determination of subjects in this study using Simple Random Sampling technique. To target the aspects of justice, usefulness, and legal certainty of consumer protection concerning the responsibilities of business actors and guaranteeing consumer rights when there are defective products in the sale and purchase transaction.

\section{Main Heading of the Analysis or Results}

Law Number 8 of 1999 concerning Consumer Protection has regulated the responsibilities of business actors in buying and selling agreements with consumers. Article 24 state "Business actors selling goods and/or services to other business actors are responsible for claims for compensation and/or consumer claims if: (a) Other business actors sell to consumers without making any changes to the goods and/or services; (b) other business actors, 
in the sale and purchase transaction do not know of any changes in goods and/or services carried out by the business actor or not in accordance with the example, quality and composition. Legal liability for the product (product liability)in the event that there is no agreement (no privity of contract) between the business actor and consumers, the responsibilities of business actors are based on product liability or product responsibility. Product liability puts the product responsibility on the business actor or known as strict liability, that is, if there is a mistake or a product defect due to or is considered a mistake by the business actor and causes loss to the consumer or other party, then it is absolutely the responsibility of the businessman, without error. This principle of responsibility stipulates that an action can be punished on the basis of harmful behavior, without questioning whether there is intentional or negligence. So the error is not a decisive factor, but there are exceptions that allow it to be freed from responsibility, for example the existence of force majure or over macht as stipulated in Article 1245 of the Civil Code.

Legal efforts taken by consumers in terms of disputes relating to the responsibilities of business actors in buying and selling transactions related to defective products consumer dispute settlement is fully regulated in the Consumer Protection Ac Chapter X which consists of four articles, starting from Article 45 to Article 48 Consumer Protection Act. The settlement of consumer disputes through this court refers to the general court provisions that apply. The proceedings in court according to the law of consumer protection use an inverse verification system. According to Law Number 30 Year 1999, settlement of disputes outside the court can be carried out by arbitration, which result in an arbitration award that is final and binding or set forth in an arbitration agreement. Settlement of disputes outside the court or better known as Alternative Dispute Resolution (ADR) can be taken in various ways. The ADR can be in the form of negotiation, meditation, conciliation, minitrial, summary jury trial, settlement conference and other forms. Consumer dispute resolution outside the court can also be done though a family approach. The legal basis is found in the Civil Code (Third Book, Chapter XVIII, Article 1851 to Article 1864 concerning peace) and in Article 45 paragraph (2) and Article 47 of the Consumer Protection Act.

\section{Conclusion}

Business actors are responsible if the product defects that occur are entirely the fault of the business actor. The responsibility of the business actor can be in the form of compensation with the same product, compensation with money equivalent to the price of the product and shipping costs, or in the form of paying for the care and treatment of consumers if the defect of the product causes health problems to consumers.

The effort taken if the business actor does not want to be responsible for the occurrence of product defects in the sale and purchase transaction is by solving the Dispute Resolution, namely: conciliation, mediation and arbitration. In addition, settlement of disputes outside the court can also be 
done with a family approach. If it does not succeed, it can be reached through a court.

\section{References}

Adrian Sutendi. (2008). Tanggung Jawab Produk Dalam Hukum Perlindungan Konsumen. Bogor: Ghalia Indonesia.

Ahmad Ali. (2002). Menguak Tabir Hukum (suatu Kajian Filosofis dan sosiologis. Jakarta: Gunung Agung.

Anna Gerbrandy. (2018). Doing Good Together: Competition Law and the Political Legitimacy of Interfirm Cooperation.

Borg and Gall. (1989). Research: An Introduction. Fifth Edition. New York, London: Longman.

Bungin, B. (2008). Metodologi Pengabdian Pada Masyarakat Kualitatif. Jakarta: PT. Rajagrafindo Persada.

Claudya, L. (2018). Perlindungan Hukum kepada Konsumen dalam Perjanjian Pembiayaan Konsumen dengan Perusahaan Finance yang menggunakan Fasilitas Channeling. Jurnal Hukum. Retrieved from hukum.studentjournal.ub.ac.id

Janus, S. (2014). Perlindungan Konsumen Di Indonesia. Bandung: Citra Aditya Bakti.

Katsoulacos, Y. (2016). Competition Law Enforcement in the BRICS and in Developing Countries: Legal and Economic Aspects. https:// doi.org/10.1007/978-3-319-30948-4

Kurniawan, B. S., \& Martin, D. (2014). Tanggung Jawab Pelaku Usaha Terhadap Pemberian Label Halal Pada Produk Makanan Dan Minuman Perspektif Hukum Perlindungan Konsumen. Jurnal Penelitian Universitas Mataram, 18 (1), 90. Retrieved from ejournal.unram.ac.id

Miru, A., \& Yodo, S. (2011). Hukum Perlindungan Konsumen. Jakarta: PT. Rajagrafindo Persada.

Muslih, M. (2013). Negara Hukum Indonesia dalam Perspektif Teori Hukum Gustav Radbruch. Legalitas Edisi Juni 2013, TV(1), 131.

Putra, S. (2014). Perlindungan Hukum terhadap konsumen dalam Transaksi Jual Beli melalui E-Commerce. Jurnal Ilmu Hukum, 4(2), 288.

Soeroso. (2006). Pengantar Ilmu Hukum. Jakarta: PT. Rajagrafindo Persada. Thornton, P. K. (2010). Livestock Production: Recent Trends, Future Prospects. Published 16 August 2010, 2853-2867. https://doi.org/DOI: 10.1098/rstb.2010.0134

Wijaya, G. (2000). Hukum Tentang Perlindungan Konsumen. Jakarta: PT. Gramedia Pustaka Utama. 